\title{
Developing E-Comic to Internalize Manners for Junior High School Students
}

\author{
Yuliana Rasyid \\ Guidance and Counseling \\ Universitas Negeri Malang, Indonesia \\ arbin.janu.fip@um.ac.id
}

\author{
Arbin Janu Setiyowati \\ Guidance and Counseling \\ Universitas Negeri Malang, Indonesia \\ arbin.janu.fip@um.ac.id
}

\author{
Elia Flurentin \\ Guidance and Counseling \\ Universitas Negeri Malang, Indonesia \\ elia.flurentin.fip@um.ac.id
}

\begin{abstract}
This study aims to develop e-comics as a media to internalize the concept of manners for junior high school students who meet the criteria of of accuracy, usefulness, convenience, and attractiveness. This research method was adapted from the Borg and Gall (1983) procedural Research and Development (R\&D) model. The subjects of this research trial were guidance and counseling experts; instructional technology experts; Linguist; and prospective users, namely counselors and junior high school students. Research data collection was using a questionnaire need assessment and interviews. Product trial data were analyzed quantitatively and qualitatively. Based on the results of the product trial evaluation it can be concluded that the product developed meets feasibility criteria, thus e-comics can be used as a media to internalize the concept of manners for junior high school students.
\end{abstract}

Keywords: development; e-comic; manners; junior high school students

\section{INTRODUCTION}

Manners is a set of regulation that is inherited and develops in a culture of society that is beneficial in the association of others, thus there is a relationship, mutual understanding, respect according to established customs (Suharti, 2004). Manners are indispensable in fostering relationships between one individual and another individual included in a relationship. The manifestation of this manners attitude is characterized by the behavior of respecting others through communication using language that does not underestimate or demean other people, and prioritizes the interests of others.

Manners and morals both have a relation with normative human behavior, which is to provide certain guidelines or norms, for instance how a person should do something and not do something. In association, manners and morals are needed in order to create a peaceful, harmonious, and orderly society order (Marzuki, 2013). A person can be said tohave a moral, if the person's behavior is in accordance with moral values that are upheld by their social group (Setiyowati \& Simon, 2014). It is important for teenagers to have a good and positive manners.

According to Havighurs, moral development is one of the most important aspect that need to be taken into account among Junior High School students (Syamsu, 2007). Adolescent has been able to perform a behaviour which does not only limited to pursue physical interest and demand. Not to mention, adolescent has been able to perceive a behaviour which pursues a pyschological deman such as acceptance feeling, being respected, and positive feedback from others. Mostly, adolescent commonly perform a behaviour which is in accordance with the general applied norms and values (Ermawati, 2013). Junior high school students are required to adjust with the norms and values which are applied to the surrounding environment based on their development phase. Kohlberg reported that one of the goals of adolescent development is optimal moral development (Hurlock, 1999).

In the argument of moral development, Kohlberg emphasizes that the level and stages of moral development are related to age. In early adolescence, especially junior high scool students, moral development tends to be at a conventional level. Adolescents tend to be easily influenced by the environment and they needs good control to prevent them to fall into negative behavior that hamper their development, especially in the aspects of manners.

Manners declining among junior high school students is commonly shown by aggressive behavior such as hostile attitude, disobeying the rules, threathening others, and disguising criticism. These manners declining is due to globalization era which forces several influences to adolescents. Manners declining, to some greater extent, leads to serious conflict, for instance conflict with parents, teachers, and peers which some of them must be proceeded with a legal settlement. In the lens of adolescent development, it hampers cognitive, affective, psychomotoric and moral construction.

Recently, some junior high school students tend to have manners declining such as saying improper words, violence among adolescents, and impolite attitude. Kurnia (2013) reports his pre-survey results through structurized interview with school counselor that manners declining of eight graders junior high school is considerably moderate. Most junior high school acquired less understanding about manners which resulted to disobeying attitude in school. Not to mention, apathetic environment and current lifestyle contribute to the manners declining 
To avoid further manners declining, it is important to foster comprehensive understanding to students about the concept of manners to construct their morality. It is indeed the responsibility of Guidance and Counseling discipline, particularly the counselors. Thus, to avoid further manners declining, counselors could internalize the concept of manners and morality within guidance and counseling service. School counselors could design an information service of guidance and counseling to internalize the understanding of manners.

Using media during the provision of guidance and counseling service offers a substantial opportunity to be involved in guidance and counseling service (Mutmainnah, dkk, 2018). Junior high school as millenials generation are mostly interested in any kind of media since they are growing up with information technology as the primary lifestyle. This enables them to easily obtain any kind of information. Therefore, to promote more involvement of junior high school in counseling service, particularly in providing manners understanding, school counselors could employe electronic comic as supplementary media.

Need analysis in the preliminary phase reported that one hundred percent of students (as much as 43 students) required a media in counseling service to assist them in developing manners understanding. Furthermore, the students demanded a comic as a media to provide four manners understanding, that is 1) respecting, 2) politeness in speaking, 3) respecting opinion of others, and 4) respecting effort of others. The four topics were arranged and designed in the form of electronic stripped comic which was uploaded in Line Webtoon. This paper seeks to develop electronic comic as a media to internalize manners understanding among junior high school students.

\section{METHOD}

The development of e-comics as a medium for internalizing manners understanding for junior high school students employed research and development approach. This study adapted Borg \& Gall's (1983) research procedure which consisted of ten steps. These steps were adapted into the following steps: (1) preliminary research and data collection, (2) comic development planning, 3) product development, (4) product trials by material experts, media experts, and linguists, ( 5) product revision based on expert trials results, (6) small group trials, (7) analysis of test results and final product revision.

In the initial stage, a needs analysis was carried out. Need assessment aims to collect data about needs that are used as a reference in the development of comics. This stage used interview methods and questionnaires for student needs. In the second stage, the developer began to formulate the objectives of e-comic media, identified material for e-comic material, and designed the comic. In the third stage, the researchers compiled comics based on four predetermined topics and uploaded them to the online comic platform Line Webtoon as a means of information and guidebooks. The fourth stage, researchers conducted a product trial. Product trials were conducted by material experts (Guidance and Counseling), media experts (Instructional Technology), linguists (Linguistics). Next, the fifth stage was product revision based on expert test results. The sixth stage, researchers conducted product tests by prospective users and small groups. In the seventh stage, the researcher presented the final product in the form of a Webtoon e-comic and a manual user.

Data analysis techniques in this research and development awee quantitative and qualitative analysis. Quantitative analysis techniques were used to obtain ecomic media assessment data and guidebooks, to calculate the appraisal data used on average. Whereas qualitative analysis was obtained from written appraisal such as suggestions for improving product valuation. Data from material expert test, media expert test, language expert test, and prospective product user test (counselor) were obtained from assessment instruments that have been developed in accordance with product specifications such as accuracy, usability, convenience and attractiveness. The formula used to find the total range is:

$$
\sum \chi=\frac{\Sigma n}{N}
$$

Remarks :

$\Sigma \chi=$ total rata-rata atau rentangan average total or range

$\Sigma \mathrm{n}=$ total score

$\mathrm{N}=$ number of element assessed

Table 1

Interpretation Scale of Expert, Media, Language Material Tests, and Prospective Product Users

\begin{tabular}{|c|c|}
\hline Score range & Criteria \\
\hline 1 & $\begin{array}{l}\text { Tidak tepat/tidak berguna/tidak mudah/tidak } \\
\text { menarik }\end{array}$ \\
\hline 2 & $\begin{array}{l}\text { Kurang tepat/kurang berguna/kurang mudah/kurang } \\
\text { menarik }\end{array}$ \\
\hline 3 & $\begin{array}{l}\text { Cukup tepat/cukup berguna/cukup mudah/cukup } \\
\text { menarik }\end{array}$ \\
\hline 4 & $\begin{array}{l}\text { Sangat tepat/sangat berguna/sangat mudah/sangat } \\
\text { menarik }\end{array}$ \\
\hline
\end{tabular}

High total range will indicate that the product is suitable for use. The range value of each aspect is interpreted with each conversion table presented in table 1

\section{RESULT}

This research and development produced e-comic as a media to internalize the understanding of manners for junior high school students. It consisted of comics and its manual book. The uploaded e-comic consisted of 1) Cover with the title of "Sopan Santun Itu Penting Loh?!"; 2) Character Introduction Part; 3) Episode 1: Respecting Other People, prolog, content, and reflection; 4) Episode 2: Politeness in Speaking, comtent and reflection; 5) Episode 3: Respecting the Other People Opinion, content and reflection; 6) Episode 4: Respecting the Other People Effort, content and reflection.

The manual book of the e-comic consisted of 1) Preface, 2) Table of Contents, 3) Chapter I: Introduction, The Purpose of Manual Book, Target User, Time and Plce of Implementation, Manual Book Components, E-comic Components, Content and Summary of Comic; 4) Chapter 
II Instruction: general instruction, specific instruction, role and task; 5) Chapter III Counseling Service Procedure: preparation and implementation; 6) Chapter IV Concluding Remarks; 7) Bibliography; 8) Appendix; and 9) Author's Biography. The manual book is used for the counselor as a manual guide to provide counseling service using e-comic to internalize the understanding of manners.

Data presentation from trial results was obtain from product trial activities carried out in two stages, 1) expert testing (material expert, media expert, and linguist), and 2) limited field testing (prospective product users and limited group testing). The presentation of trial data was presented in quantitative and qualitative data.

A trial of e-comic products was needed in this study before being used in providing counseling service in schools. Data from material experts, media experts, linguists and prospective counselor users is supporting data to test the feasibility of e-comic. The following are the results of the expert and prospective user trial on the product as a whole.

Table 2

Trial Results of E-comic

\begin{tabular}{|c|l|c|}
\hline \multirow{2}{*}{ No } & \multicolumn{1}{|c|}{ Subject } & Score \\
\cline { 3 - 3 } & & E-comic product \\
\hline 1 & Subject Matter Expert & 3,9 \\
\hline 2 & Media Expert & 4 \\
\hline 3 & Linguist & 3,2 \\
\hline 4 & $\begin{array}{l}\text { Prospective User } \\
\text { (Conselor) }\end{array}$ & 4 \\
\hline Total & & $\mathbf{1 5 , 1}$ \\
\hline Avg & $\mathbf{3 , 8}$ \\
\hline
\end{tabular}

Table 2 above shows that the assessment of ecomics as a medium for internalizing the understanding of manners for junior high school students reached an average score of 3.8. This value means that e-comics are very suitable as a medium for internalizing the understanding of manners for junior high school students.

The results of trials on students as prospective users are supporting data to test the level of product feasibility. Trials on students as prospective users were conducted in Class VIII C and eight students were randomly selected. The table below is the result of a trial to students using e-comics.

Table 3

Trial Results from Prospective Users (Counselors)

\begin{tabular}{|c|c|c|}
\hline \multirow{2}{*}{ No } & Subject & Score \\
\cline { 3 - 3 } & & E-comic product \\
\hline 1 & Subject 1 & 3,7 \\
\hline 2 & Subject 2 & 3,9 \\
\hline 3 & Subject 3 & 3,7 \\
\hline 4 & Subject 4 & 3,3 \\
\hline 5 & Subject 5 & 3,5 \\
\hline 6 & Subject 6 & 3,9 \\
\hline 7 & Subject 7 & 3,4 \\
\hline 8 & Subject 8 & 3,6 \\
\hline Total Score & $\mathbf{2 9}$ \\
\hline Avg & $\mathbf{3 , 6}$ \\
\hline
\end{tabular}

Table 3 above shows that the trial results to students as prospective users obtained an average score of 3.6. The figure shows that this product is said to be very feasible and can be used in guidance and counseling information services. The feasibility is seen by the suitability of the product in the form of e-comics based on the assessment of prospective user trials.

\section{DISCUSSION}

At the trials phase, the initial e-comic product and its manual book required some revision. In the first stage, the assessment was carried out by subject matter experts, media experts, and linguists. In addition, e-comics were also assessed by prospective users (counselors) and through the small group trials stage (students). Based on the overall results obtained, the developed e-comic media is very feasible because it meets the criteria of accuracy, usability, convenience, and attractiveness.

Furthermore, the product was considered very appropriate based on the experts assessment and trials to prospective users. The assessment results confirmed that the e-comic has covered the entire components of manners concept. Manners as a concept commonly consisted of certain behavior such as respecting others, using proper language when speaking, and do not underestimate others (Suharti, 2004).

The manners component in e-comics developed by researchers includes all the important components of manners that must be understood by middle school students as explained by Endraswara (2010) where the comic covers ten sections which are summarized into four main topics. The e-comic material contained in this development product, according to the manners indicator, is respecting others, speaking politely, respecting other people's opinions, and valuing the efforts of others. These indicators serve as the main content or topic in the story. Stories used in e-comics use language that is easy and can be understood by students. This is adjusted to Yusuf (2011) 's statement that language is very closely related to the development of thinking of someone who is able to form understanding, arrange opinions and draw conclusions.

In the outline of the story in e-comics, characters who do not have manners are displayed. In the title "Manners Itu Penting Loh?!" (Manners Are Important), Ade, one of the character, represent a kid with no manners and good behavior. Until at a certain time Ade felt disrespected by the people around him and eventually began to show good manners and behavior in order to respect each other. Widayati (2008) argues that manners and behavior have an important element in everyone's daily social life, because by showing good manners, one can be valued and favored. Broadly speaking, the stories in e-comic concern the affective domain. Growth of character is included in the affective aspect (attitude). In Bloom's Taxonomy, the affective aspect consists of five stages, namely acceptance, response, appreciation, organization, and characterization based on values (Rahayu, 2016). Based on the characters mentioned above, it can be said that the content about manners in this product is in accordance with the theory of manners expressed by Suharti, Endraswara, and Taxonomy.

This product is considered very easy based on expert and prospective product user assessment because there are instructions for use consisting of general and specific instructions as well as Webtoon e-comics operating procedures. The operation of e-comics on 
Webtoon makes it easy for students to use it because today's students are already attached to the world of technology. Wahana (2015) suggested that millennial adolescence is a period that has a very strong sensitivity to new things, so they are very easy to adapt to something new. One of the impacts for digital age students is the ease of sharing information or receiving information. Through e-comics, it can be easier for counselors to collaborate on e-comics by adjusting the needs of current students.

Manual book as a guide to the use of e-comics contains instructions in the form of planning stages, implementation stages to the evaluation stage. This product is also considered"very useful" as a counselor's reference in providing guidance and counseling services through the use of media. In addition, e-comics is also considered "very useful" because they can provide information that is suitable for students' needs and can also be new content or input from the readers of this Webtoon e-comic. This is because in Line Webtoon, the communication that occurs is two-way, that is, the reader does not become a silent reader since the reader can participate in the comments column provided in the form of suggestions or criticism (Medina, 2016).

The product developed has met the attractiveness criteria, is categorized very interesting, based on the opinion of experts and prospective users. Cover, appearance (border), and the contents of the developed manual book are considered very interesting. Not only that, the e-comic that was developed was also considered attractive in terms of the cover, title, composition of images and colors, characters in the comics, as well as the storyline and messages contained. Zain, et al (2013) stated the reason students like comics as a learning medium is that comics are more interesting, more comfortable to read, easier to understand because they are accompanied by pictures, are more fun because they have a story line, and are not boring. A good comic must have a good function that educates the reader and always has a moral message delivered (Soedarso, 2015).

After receiving input from material experts, linguists, researchers made revisions to improve the ecomic media and manual book. However, not all suggestions were used as revision materials because researchers adjusted to the ease for readers to understand. Improvements to the e-comic media as a whole have been good, but a slight addition to the revisions made is the addition of the story line to reinforce the story message content, while the revised guidebook is the improvement of writing and RPLBK.

Based on the results of the trial process conducted by researchers, several advantages and disadvantages of e-comic media can be explained. Webtoon e-comics about manners has several advantages, including: 1) Webtoon ecomics consist of materials that have been adapted to the needs of students, 2) this media can be used as a counselor's reference in providing services about manners to students related to local culture, 3 ) the media consists of four episodes with different topics developed can be chosen by students, 4) this media was developed as an alternative counseling service that is interesting, and easy to use, 5) e-comics This webtoon can last a long time, dynamic, and easily accessed at any time, 6) this media is part of the identity and lifestyle of today's adolescnet who are attached to technology, and 7) E-comics Webtoon has free access to be downloaded using an internet network. However, to access the comic, students need an internet connection. Thus, if they have no connection, the e-comic cannot be accessed.

\section{CONCLUSION}

This research and development resulted e-comics and its manual book as a media for internalizing the concept of manners for junior high school students. This development product has gone through a systematic process starting from conducting needs analysis, development planning, developing information service media, conducting product trials by material experts, media experts, linguists, prospective users and small groups. The product trial was also revised based on suggestions and input so the product can be said to be theoretically feasible and practical.

Based on the research results obtained, the authors suggest that 1) the counselor in using e-comics as one of the media internalization of the value of the manners must understand the guidance procedures and guidance material contained in the manual book to achieve the expected goals, 2) counselors are advised to collaborate with subject teachers in providing services to students, 3) further research is advised to assess the effectiveness of ecomics as a media for internalizing the value of manners for students.

\section{REFERENCES}

[1] Borg \& Gall, M.D. 1983. Educational Research An Introduction. Broadway, New York: Longman Inc.

[2] Endraswara, S. 2010. Etika Hidup Orang Jawa. Yogyakarta: Narasi.

[3] Ermawati, A.Y.2013. Pengembangan Paket Bimbingan Etiket Pergaulan Untuk Siswa SMP Negeri 2 Tulungagung. Skripsi tidak diterbitkan. Malang: FIP UM.

[4] Hidayah, N. 2017. Pengembangan Media Pembelajaran Berbasis Komik Pada Mata Pelajaran Ilmu Pengetahuan Sosial Kelas IV MI Nurul Hidayah Roworejo Negerikaton Pesawaran. Jurnal Pendidikan dan Pembelajaran Dasar 4(1), 34-46. Dari http://http://ejournal.radenintan.ac.id/index.php/terampil/ar ticle/download/1804/1477.

[5] Hurlock, E.B. 1999. Psikologi Perkembangan: Suatu Pendekatan Sepanjang Rentang Kehidupan. Edisi Kelima. Jakarta: Erlangga.

[6] Kurnia, Y. 2013. Hubungan Pemahaman Konsep Adab Manners Dengan Perubahan Sikap Siswa. (Online), (www.e-jurnal.com/2015/09/hubungan-pemahamankonsep-adab-sopan_16.html), diakses 4 April 2018.

[7] Marzuki. 2013. Etika dan Moral Dalam Pembelajaran. (Online),

(http://staff.uny.ac.id/sites/default/files/penelitian/drmarzuki-mag/49-etika-dan-moral-dalam-pembelajaranmarzuki-2013.pdf), di akses 5 Februari 2019.

[8] Medina, Z. 2016. Motif Pengguna Aplikasi Line Webtoon (Studi Deskriptif Kuantitatif Pada Pengikut Akun Official Line Webtoon ID, (Online), (https://id.scribd.com/document/369637303/JurnalWebtoon), diakses 30 Juli 2019

[9] Mutmainnah, A.N., Yulidah, R., \& Yuniarti, S. 2018. Media Bimbingan Konseling Berbasis Hypermedia. Makalah disajikan dalam Seminar Nasional Penerapan 
Panduan Operasional Penyelenggaraan (POP) Bimbingan dan Konseling di Sekolah Dalam Menyikapi Tantangan Profesi BK di Abad 21, Jurusan BK FIP-UPGRIS, Semarang, November 2017.

[10] Rahayu, T. 2016. Penumbuhan Budi Pekerti Melalui Gerakan Literasi Sekolah. The Progressive and Fun Education Seminar. $179^{-} 183 . \quad$ Dari http://https://publikasiilmiah.ums.ac.id/bitstream/handle/1 1617/7644/20.pdf?sequence $=1$.

[11] Setiyowati, A.J., \& Simon, I.M. 2014. Pengembangan Komik Moral Sebagai Layanan Informasi Bagi Siswa SMP. Prosiding Seminar Nasional, 280²86. Dari http://karya-ilmiah.um.ac.id/index.php/karya-dosenfip/article/view/73221/4825.

[12] Soedarso, N. 2015. Komik:Karya Sastra Bergambar. Humaniora, 6, 496-506.

[13] Suharti. 2004. Pendidikan Manners dan Kaitannya dengan Perilaku Berbahasa Jawa Mahasiswa. Jurnal FBS UNY, 11(1), 57-71. Dari http://eprints.uny.ac.id/5064/1/Pendidikan_Sopan_Santun. pdf.
[14] Wahana, H.D. 2015. Pengaruh Nilai-Nilai Budaya Generasi Millenial dan Budaya Sekolah Terhadap Ketahanan Individu. Jurnal Ketahanan Nasional 21(1), $14^{-} 22$.

Dari http://https://www.researchgate.net/publication/310736067 _Pengaruh_Nilai-

Nilai_Budaya_Generasi_Millennial_Dan_Budaya_Sekola h_Terhadap_Ketahanan_Individu_Studi_Di_SMA_Negeri _39_Cijantung_Jakarta.

[15] Widayati, S \& Widijati, U. 2008. Mengoptimalkan 9 Zona Kecerdasan Majemuk Anak. Yogyakarta: Luna Publisher.

[16] Yusuf, S. 2011. Psikologi Perkembangan Anak dan Remaja. Bandung: PT. Remaja Rosdakarya.

[17] Zain, N.H., dkk. 2013. Pengembangan Komik Bahan Ajar IPA Terpadu Kelas VIII SMP pada Tema Sistem Pencernaan Manusia dan Hubungannya dengan Kesehatan. (Online). (https://journal.unnes.ac.id/sju/index.php/usej/article/view/ 1826), di akses 19 Desember 2018. 